Original scientific paper - Izvorni znanstveni rad

UDK: 637.112 .2

\title{
Effect of temperament on milk production, somatic cell count, chemical composition and physical properties in Lacaune dairy sheep breed
}

doi: 10.15567/mljekarstvo.2017.0403

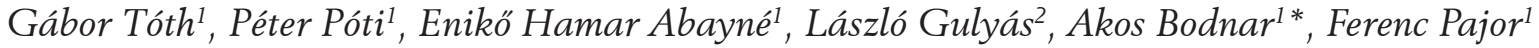 \\ ${ }^{1}$ Szent Istvan University, Institute of Animal Husbandry, Páter K. 1., H-2100 Gödöllő, Hungary \\ ${ }^{2}$ Széchenyi Istvan University, Institute of Animal Husbandry, Vár 2, H-9200 Mosonmagyaróvár, Hungary
}

Received - Prispjelo: 29.11.2016. Accepted - Prihvaćeno: 27.09.2017.

\begin{abstract}
Effect of temperament on milk yield, lactation length, physico-chemical properties and somatic cell count of Lacaune ewes were evaluated. The investigation was carried out at a sheep farm in the county of Győr-Moson-Sopron. The temperament of 106 Lacaune ewes was measured by the temperament 5 -point-scale test $(1=$ very nervous, $5=$ very quiet $)$ during milking. Furthermore, 42 ewes were randomly selected from a herd of 106 animals for the analysis of milk composition (fat, protein and lactose), $\mathrm{pH}$, electrical conductivity as well as somatic cell count. It was found that the temperament had a significant effect on lactation length and lactation milk production, lactose, electrical conductivity and somatic cell count. Calm ewes had significantly longer lactation (4 score: 220.7 day; 5 score: 201.4 day) as well as higher milk production (4 score: $207.9 \mathrm{~kg} ; 5$ score: $193.3 \mathrm{~kg}$ ) compared to more temperamental animals $(2+3$ scores: 166.5 day and $135.5 \mathrm{~kg}$; $\mathrm{P}<0.05)$. The content of lactose was significantly lower (4.32) in the more temperamental group, while electrical conductivity was higher $\left(4.81 \mathrm{mS} \mathrm{cm}^{-1}\right)$ compared to calmer animals ( $4.69 \%$ and $4.16 \mathrm{mS} \mathrm{cm}^{-1}$ ). Additionally, significant differences were found in milk somatic cell count among the temperament categories. Calmer ewes had a lower somatic cell count in milk $\left(5.17 \log \mathrm{cm}^{-3}\right)$ than more temperamental ones $\left(5.67 \log \mathrm{cm}^{-3} ; \mathrm{P}<0.05\right)$.
\end{abstract}

Key words: ewe milk, temperament, milk yield, somatic cell count, electrical conductivity

\section{Introduction}

The research on the temperament of domesticated animals became more important in the recent years. Several production traits were linked to temperament scores: calmer animals have better production parameters (higher weight gain, more favourable meat quality) compared to more temperamental animals (Dodd et al., 2014; Bokor et al., 2016). Temperament is generally defined in terms of the behavioural response to human handling or to a novel environment (Sutherland et al., 2012). Several authors reported that milking temperament such as stepping behaviour at milking is a main characteristic of dairy animals that indicates the level of stress during milking (Szentléleki et al., 2015).
Animals' temperament has been often evaluated by subjectively scoring where authors generally use 1-3, 1-4 or 1-5 scoring scales to identify animals' temperament during milking in a milking parlour (Szentléleki et al., 2015). Previous studies reported correlations between temperament and lactation milk production in dairy sheep (Murray et al., 2009; Pajor et al., 2010, Pajor et al. 2013). According to these results, calmer animals produced more milk than nervous ones. Earlier studies have focused on the differences in milk production traits related to distinct temperament scores. However, in some published papers there was no available information about relationship between the temperament score and somatic cell count in milk. Some authors found 
relationship between these traits in cattle and buffalo, more temperamental animals have higher somatic cell counts (Orbán et al., 2011; Carvalhal et al., 2017). Hypothesis of this study was that the more temperamental animals have higher somatic cell count in milk during the whole lactation period compared to the calmer ones.

The somatic cell count (SCC) in the milk of healthy ewes does not reach 250.000 cells $\mathrm{cm}^{-3}$, but SCC between 250.000-1.000.000 cells $\mathrm{cm}^{-3}$ often occurs in the milk of ewes which does not show the symptoms of mastitis (Paape et al., 2007). In some cases, the temperament has been influenced also by parities so that the multiparous dairy animals were calmer than primiparous animals (Szentléleki et al., 2015).

The aim of this study was to investigate the effect of temperament on milk yield, lactation length, milk chemical and physical parameters, $\mathrm{pH}$, electrical conductivity and somatic cell count in Lacaune ewes.

\section{Materials and methods}

\section{Experimental design}

This study was carried out in a Hungarian dairy sheep farm (Mórichida: 47²9'10.5”N $17^{\circ} 25^{\prime} 18.4^{\prime \prime E}$ ). Data were collected from 106 multiparous (parities: 2-5 lactations; $n=45,18,27$ and 16) Lacaune ewes which had neither signed clinical mastitis symptoms (swelling, heat, redness or pain) nor foot-health problem. Individual milk production (milk yield and lactation length) of the ewes has been calculated on the basis of monthly monitoring made by the Hungarian Sheep and Goat Breeder Association. Moreover 42 ewes (parities: 2-4 lactations; $n=23,7$ and 12) were randomly selected from a herd of 106 animals for the analysis of milk traits: chemical composition (fat, protein and lactose), $\mathrm{pH}$, electrical conductivity and somatic cell count.

The study and milking period started in midMarch. The animals in the same lactation stage were kept free in the stable and were milked in $2 \times 24$ Hungaro Lact milking parlour two times per day. Nutrition of the animals was based on pasture during the whole study. The grazing period started in mid-April. The main grassland species were
Lolium perenne, Poa pratensis, Festuca rubra, and the main legume was Lotus corniculatus. Additionally, all animals were fed by $400 \mathrm{~g}_{\text {day }}{ }^{-1}$ concentrate (NE: $7.1 \mathrm{MJ} \mathrm{kg}^{-1} \mathrm{DM}$; crude protein: $180 \mathrm{~g} \mathrm{~kg}^{-1} \mathrm{DM}$, containing vitamins $\left.\mathrm{A}, \mathrm{D}_{3}, \mathrm{E}\right)$ and ad libitum alfalfa hay (NE: $5.1 \mathrm{MJ} \mathrm{kg}^{-1} \mathrm{DM}$; crude protein: $189 \mathrm{~g} \mathrm{~kg}^{-1}$ DM). Commercial trace-mineralized salt blocks (ad libitum) were an integral part of the nutrition.

The temperament of ewes was evaluated on the $48^{\text {th }}, 74^{\text {th }}$ and $103^{\text {th }}$ day of their lactation during the morning and evening milking. Behaviour of animals was evaluated by a 5 -score system during the whole duration of udder preparation and milking procedure (Budzynska et al., 2005) by direct scoring:

1) very nervous, continual and vigorous stepping and kicking;

2) continual and vigorous stepping but there is no kicking;

3) occasionally vigorous leg movements;

4) quiet standing with few slight leg movements;

5) very quiet, no leg movements.

Milk samples were collected in a triplicate immediately after temperament scoring in the morning and evening. Milk composition (fat, protein and lactose) was determined using a LactoScope ${ }^{\mathrm{TM}}$ (Delta Instruments Ltd., Netherlands) device. The $\mathrm{pH}$ and electrical conductivity values of the sheep milk were measured by Extech EC500 (Extech Instruments, Nashua, NH, USA) pH and conductivity meter. The milk somatic cell count was determined by Bentley FCM device at Livestock Performance Testing Ltd (Gödöllő, Hungary).

\section{Statistical analysis}

Statistical analysis was performed by the SPSS 23.0 software package. The Kruskal-Wallis test was used to assess the differences among temperament scores during experimental period, and to study the differences in the mean temperament scores within the parities, too. Before analysis, Shapiro-Wilk's test was used for testing the normality distribution. The somatic cell count data were transferred to logarithm (with logarithm base 10) before statistical evaluations. The numbers of ewes with temperament scores 2 and 3 were relative low therefore they have been merged into a group $(2+3)$. Statistical analysis was carried out in order to determine the effect of temperament and parity (fixed factors) on 
milk chemical and physical properties, somatic cell count and production as dependent variables. The multivariate general linear model (GLM) procedure was used to analyse variance. The statistical model was as following:

$$
\mathrm{Y}_{\mathrm{ij}}=\mu+\mathrm{A}_{\mathrm{i}}+\mathrm{B}_{\mathrm{j}}+\mathrm{e}_{\mathrm{ij}}
$$

where $Y_{i j}$ is the value of the dependent variable, $\mu$ is the overall mean, $A_{i}$ is the effect of parity, $B_{i}$ is the effect of temperament score and $\mathrm{e}_{\mathrm{ij}}$ is the random error. Statistical significances between groups were calculated with Tukey HSD post-hoc test.

\section{Results and discussion}

The descriptive statistics of milk production traits are showed in Table 1 . The average value of somatic cell counts was 580000 cells $\mathrm{cm}^{-3}$, fat and protein content was $7.03 \%$ and $5.65 \%$, and average milk yield was $193.70 \mathrm{~kg}$. Values of milk parameters were in line with reports of several authors (Park et al., 2006; Paape et al., 2007; Makoviczky et al., 2013 and 2014). The Lacaune ewes' milk production was higher compared to data published by Hungarian Sheep and Goat Breeder Association (average milk yield: $145.1 \mathrm{~kg}$; length of lactation: 129.7 day) (HSGBA, 2013).
The parity significantly affected daily and lactation milk yield $(\mathrm{F}=5.70$ and 10.45; $\mathrm{P}<0.001$ in both), which was in line with past studies (Oravcova et al., 2006) (not presented in Table). However, temperament scores of ewes were not affected by parity $(\mathrm{KW}=0.226, \mathrm{P}=0.973)$. Therefore, the temperament score data of animals of different parity were merged in this experiment. Results of lactation length and lactation milk production traits of Lacaune ewes by temperament scores are presented in Table 2. The temperament of individual animals was constant $(\mathrm{KW}=2.064, \mathrm{P}=0.356)$ during the investigation. In our study, $45.4 \%$ of Lacaune ewes got score "5" (calm animals), $39.1 \%$ of ewes got score " 4 ", $8.2 \%$ of ewes got score " 3 " and $7.3 \%$ of animals got score "2". Animal with score " 1 " was not found in this investigation. Similar results had been reported earlier by Szentléleki et al. (2015) who found that approximately $90 \%$ of dairy cows were calm in their studies. Based on our results, proportion of Lacaune ewes with unfavourable temperament score during milking was low.

The average daily milk yield of ewes did not show significant difference among the temperament categories. However, calm ewes had higher $(\mathrm{P}<0.001)$ lactation length $(4$ and 5 score: 210.78

Table 1. Basic descriptive statistics of milk chemical parameters, milk production and somatic cell count in Lacaune herd $(n=106)$

\begin{tabular}{lccccc}
\hline Investigated traits & Mean & SD & SEM & Minimum & Maximum \\
\hline Milk fat, \% & 7.03 & 0.95 & 0.15 & 4.92 & 8.11 \\
\hline Milk protein, \% & 5.65 & 0.23 & 0.03 & 5.21 & 6.14 \\
\hline Lactose, \% & 4.64 & 0.29 & 0.04 & 3.18 & 5.09 \\
\hline Lactation length, day & 204.38 & 37.17 & 3.61 & 115 & 259 \\
\hline Milk yield, kg & 193.70 & 43.49 & 4.23 & 54.70 & 380.40 \\
\hline SCC log cm & 5.80 & 0.52 & 0.08 & 4.58 & 6.78 \\
\hline
\end{tabular}

Table 2. Least squares means of ewes' milk production traits by temperament categories

\begin{tabular}{lccccc}
\hline \multirow{2}{*}{ Investigated traits } & \multicolumn{3}{c}{ Temperament } & \multirow{2}{*}{ SEM } & \multirow{2}{*}{ P-values } \\
\cline { 2 - 4 } & $2+3$ & 4 & 5 & & 106 \\
\hline $\mathrm{n}$ & 13 & 43 & 50 & & 100 \\
\hline$\%$ & 12.2 & 40.6 & 47.2 & & $<0.001$ \\
\hline Lactation length, day & $166.47^{\mathrm{a}}$ & $220.66^{\mathrm{b}}$ & $201.39^{\mathrm{c}}$ & 4.130 & $<0.001$ \\
\hline Milk production, $\mathrm{kg}$ & $135.52^{\mathrm{a}}$ & $207.90^{\mathrm{b}}$ & $193.25^{\mathrm{b}}$ & 4.414 & 0.001 \\
\hline Average daily milk yield, $\mathrm{kg}$ & $0.82^{\mathrm{a}}$ & $0.94^{\mathrm{b}}$ & $0.97^{\mathrm{b}}$ & 0.016 & 0.00 \\
\hline
\end{tabular}

+2: continual and vigorous stepping but there is no kicking; 3: occasionally vigorous leg movements; 4: quiet standing with few slight leg movements; 5: very quiet, no leg movements abc $\mathrm{P}<0.05$ different letters indicate significant differences in a row 
and 199.82 day) as well as milk production $(\mathrm{P}<0.001 ; 201.73$ and $194.15 \mathrm{~kg})$ compared to the more temperamental animals $(83.67$ day and $80.07 \mathrm{~kg})$.

Our results suggested that temperament had great effect on milk production and lactation length. It was already reported that calmer animals tend to have higher milk production level compared to temperamental ewes (Murray et al., 2009; Pajor et al., 2010, 2013), but there were not any earlier data reported about the effect of temperament on lactation length. In contrast, no relation had been found between average daily milk yield and temperament score, which is correspondent with Murray et al. (2009); Pajor et al. (2010) and Pajor et al. (2013).

In other group, parity had no significant effect on the physico-chemical properties and somatic cell count of the milk which was in concordance with the literature reports (Králíčková et al., 2011). Results considering the composition and characteristics of Lacaune ewes milk (fat, protein and lactose contetnt, $\mathrm{pH}$, electrical conductivity, somatic cell count) were related to temperament scores are presented in Table 3. There were no differences in milk fat and protein composition and $\mathrm{pH}$ among the temperament categories. Nevertheless, some previous reports showed differences in milk protein content among temperament categories. Higher protein content was found in calm Merino sheep milk rather than in nervous ewes' milk (Murray et al., 2009). On contrary, the temperament significantly affected both, lactose content $(\mathrm{P}<0.05)$ and electrical conductivity $(\mathrm{P}<0.05)$. The more temperamental group ("2" and " 3 " scores) had lower lactose content and higher electrical conductivity than the calmer one. Electrical conductivity of milk was well documented as a good indicator for the detection of mastitis, as well as increasing conductivity with increasing somatic cell count, which corresponded to earlier literature data (Diaz et al., 2011). Nowadays, it is often used in practice, especially in large-scales dairy farms.

We found that calmer ewes had lower somatic cell count. The calm animals (" 5 " score) had a lower somatic cell count $\left(5.17 \log \mathrm{cm}^{-3}\right)$ in comparisonto the more temperamental (" 2 " and " 3 " scores) ewes (5.67 $\log \mathrm{cm}^{-3}, \mathrm{P}<0.05$ ). Earlier studies did not supply detailed information about the relationship between the temperament and somatic cell count in ewe milk. Moreover, Orbán et al. (2011) found that cows with unfavourable temperament showed lower somatic cell counts. Most of the somatic cells of healthy animals are epithelial cells originating from the inner surface of the udder. Opposite to this, somatic cells of an infected organism are mainly leukocytes. These cells appear in increased amounts in milk as an immune response to an udder pathogen bacteria species. Leukocytes cells play an important role in the immune response acting as phagocytes (Lindmark-Mansson et al., 2006). Immune system has been reported to be influenced by temperament (Fell et al., 1999). Some authors reported that nervous animals had lower serum concentrations of IgG and lymphocyte proliferation compared to calm animals (Olfe et al., 2010). Our result suggested that the higher milk somatic cell can be caused by the declined immune system featured in the more temperamental animals.

Table 3. Least squares means of ewes milk chemical and physical parameters and somatic cell count by temperament categories

\begin{tabular}{lccccc}
\hline \multirow{2}{*}{ Investigated traits } & \multicolumn{3}{c}{ Temperament ${ }^{+}$} & \multirow{2}{*}{ SEM } & \multirow{2}{*}{ P-values } \\
\cline { 2 - 4 } & $2+3$ & 4 & 5 & & 42 \\
\hline $\mathrm{n}$ & 8 & 11 & 23 & & 100 \\
\hline Milk fat, \% & 19.0 & 26.2 & 54.8 & & 0.672 \\
\hline Milk protein, \% & 7.15 & 6.87 & 7.18 & 0.180 & 0.185 \\
\hline Lactose, \% & 5.79 & 5.60 & 5.65 & 0.042 & 0.032 \\
\hline $\mathrm{pH}$ & $4.36^{\mathrm{a}}$ & $4.61^{\mathrm{b}}$ & $4.67^{\mathrm{b}}$ & 0.052 & 0.677 \\
\hline Electrical conductivity, $\mathrm{mS} \mathrm{cm}^{-1}$ & 6.65 & 6.67 & 6.64 & 0.017 & 0.041 \\
\hline SCClog cm $^{-3}$ & $4.57^{\mathrm{b}}$ & $4.22^{\mathrm{a}}$ & $4.19^{\mathrm{a}}$ & 0.068 & 0.016 \\
\hline
\end{tabular}

+2: continual and vigorous stepping but there is no kicking; 3: occasionally vigorous leg movements; 4: quiet standing with few slight leg movements; 5 : very quiet, no leg movements

ab $\mathrm{P}<0.05$ different letters indicate significant differences in a row 


\section{Conclusions}

In conclusion, the calmer ewes had lower somatic cell count in milk and higher milk production than temperamental ones. The temperament score also affected the electrical conductivity and lactose content. These results proved that the application of temperament score test was beneficial for breeders due to the fact that the calmer ewes produced more milk with reduced somatic cell counts than nervous animals.

\section{Acknowledgements}

The authors would like to say thank for assistance of Ede Sipos. This work was supported by the Research Centre of Excellence-1476-4/2016/FEKUT project.

\section{Učinak temperamenta na količinu mlijeka, broj somatskih stanica, kemijski sastav $i$ fizikalna svojstva pasmine Lacaune ovaca}

\section{Sažetak}

Istražen je utjecaj temperamenta na količinu mlijeka, duljinu laktacije, fizikalno-kemijska svojstva i broj somatskih stanica Lacaune pasmine ovaca. Istraživanje je provedeno na farmi ovaca u županiji Győr-Moson-Sopron. Temperament 106 ovaca pasmine Lacaune određivan je tijekom mužnje pomoću temperament testa s ljestvicom od 5 stupnjeva ( $1=$ jako nervozne, 5 = vrlo tihe). Nadalje, 42 ovce nasumično su odabrane iz stada koje je sačinjavalo 106 životinja za analizu sastava mlijeka (masti, proteina i laktoze), $\mathrm{pH}$, električne vodljivosti te broja somatskih stanica. Utvrđeno je da temperament ima značajan utjecaj na duljinu laktacije i proizvodnju mlijeka u laktaciji, laktozu, električnu vodljivost i broj somatskih stanica. Smirene ovce imale su značajno dulju laktaciju (4 boda: 220,7 dan, 5 bodova: 201,4 dan), kao i veću proizvodnju mlijeka (4 boda: 207,9 kg, 5 bodova: 193,3 kg) u usporedbi s temperamentnim životinjama $(2+3$ bodova: $166,5$ dan i $135,5 \mathrm{~kg}, \mathrm{P}<0,05)$. Sadržaj laktoze bio je znatno niži $(4,32 \%)$ u temperamentnijoj skupini, dok je električna vodljivost bila veća $\left(4,81 \mathrm{mS} \mathrm{cm}^{-1}\right)$ u usporedbi sa smirenim životinjama $(4,69 \%$ i $\left.4,16 \mathrm{mS} \mathrm{cm}^{-1}\right)$. Dodatno, značajne razlike utvrđene su u broju somatskih stanica u mlijeku različitih temperamentnih kategorijama. Smirenije ovce imale su manji broj somatskih stanica u mlijeku $\left(5,17 \log \mathrm{cm}^{-3}\right)$ od onih temperamentnih $\left(5,67 \log \mathrm{cm}^{-3}, \mathrm{P}<0,05\right)$.

Ključne riječi: ovčje mlijeko, temperament, količina mlijeka, broj somatskih stanica, električna vodljivost

\section{References}

1. Bokor, B., Póti, P., Abayné, H.E., Kerti, A., Szabó, Cs., Morlin, Zs., Pajor, F. (2016): Effect of temperament on some blood biochemical parameters and growing traits of lambs during fattening. Journal of Animal Research 6, 367-370. https://doi.org/10.5958/2277-940X.2016.00032.2

2. Budzynska, B., Ceglinska, A., Kamieniak, J., Krupa, W., Sapula, M (2005): Behaviour of dairy cows during premilking udder preparation. Book of Abstracts of the $4^{\text {th }}$ International Congress on Ethology in Animal Production, pp. 33-35.

3. Carvalhal, M.V.L., Sant'Anna, A.C., Páscoa, A.G., Jung, J., Costa, M.J.R.P. (2017): The relationship between water buffalo cow temperament and milk yield and quality traits. Livestock Science 198, 109-114. https://doi.org/10.1016/j.livsci.2017.02.016

4. Diaz, J.R., Romero, G., Muelas, R., Sendra, E., Pantoja, J.C.F., Paredes, C. (2011): Analysis of the influence of variation factors on electrical conductivity of milk in Murciano-Granadina goats. Journal of Dairy Science 94, 3885-3894. https://doi.org/10.3168/jds.2011-4187

5. Dodd, C.L., Hocking Edwards, J.E., Hazel, S.J., Pitchford, W.S. (2014): Flight speed and agitation in weaned lambs: Genetic and non-genetic effects and relationships with carcass quality. Livestock Science 160, 12-20. https://doi.org/10.1016/j.livsci.2013.12.001

6. Fell, L.R., Colditz, I.G., Walker, K.H., Watson D.L. (1999): Associations between temperament, performance and immune function in cattle entering a commercial feedlot. Australian Journal of Experimental Agriculture 39, 795-802.

7. HSGBA (2013): Hungarian Sheep and Goat Breeder Association. Results of breeding and production in 2013. www.mjksz.hu (last download: 2015. 10. 01.)

8. Králičková, Š., Pokorná, M., Kuchtík, J., Filipčík, R. (2011): Effect of parity and stage of lactation on milk yield, composition and quality of organic sheep milk. Acta Universitatis Agriculturae et Silviculturae Mendelianae Brunensis 60, 71-78. https://doi.org/10.11118/actaun201260010071 
9. Lindmark-Mansson H., Branning, C., Alden, G., Paulsson, M. (2006): Relationship between somatic cell count, individual leukocyte populations and milk components in bovine udder quarter milk. International Dairy Journal 16, 717-727. https://doi.org/10.1016/j.idairyj.2005.07.003

10. Makoviczky, P., Nagy, M., Makoviczky, P., Szinetár, Cs. (2013): Milk quality comparison of sheep breeds (Improved Valachian, Tsigai, Lacaune) and their crosses. Magyar Állatorvosok Lapja 135, 85-90.

11. Makovický, P., Makovický, P., Nagy, M., Rimárová, K., Diabelková, J. (2014): Genetic parameters for somatic cell count, LOGSCC and somatic cell score among breeds: Improved Valachian, Tsigai, Lacaune and their crosses. Acta Veterinaria-Beograd 64, 386-396.

12. Murray, T.L., Blache, D.B., Bencini, R. (2009): The selection of dairy sheep on calm temperament before milking and its effect on management and milk production. Small Ruminant Research 87, 45-49. https://doi.org/10.1016/j.smallrumres.2009.10.005

13. Olfe J., Domanska, G., Schuett, C. Kiank, C. (2010): Different stress-related phenotypes of BALB/c mice from in-house or vendor: alterations of the sympathetic and HPA axis responsiveness. BMC Physiology 10 (2).

14. Oravcová, M., Margetín, M., Peškovičová, D., Daňo, J., Milerski, M., Hetényi, L., Polák P. (2006): Factors affecting milk yield and ewe's lactation curves estimated with test-day models. Czech Journal of Animal Science 51, 483-490.

15. Orbán, M., Kovácsné, G.K., Pajor, F., Szentléleki, A., Póti, P., Tőzsér, J., Gulyás, L. (2011): Effect of temperament of Jersey and Holstein Friesian cows on milk production traits and somatic cell count. Archiv Tierzucht 54, 594-599.
16. Pajor, F., Murányi, A., Szentléleki, A., Tőzsér, J., Póti, P. (2010): Effect of temperament of ewes on their maternal ability and their lambs' postweaning traits in Tsigai breed. Archiv Tierzucht 53, 465-474.

17. Pajor, F., Gulyás, L., Szücs, T., Póti, P. (2013): Effect of temperament on milk production of Lacaune ewes in a herd (In Hungarian). Allattenyésztés és Takarmányozás 62, 37-44.

18. Paape, M.J., Wiggans, G.R., Bannerman, D.D., Thomas, D.L., Sanders, A.H., Contreras, A., Moroni, P., Miller, R.H. (2007): Monitoring goat and sheep milk somatic cell counts. Small Ruminant Research 68, 114-125. https://doi.org/10.1016/j.smallrumres.2006.09.014

19. Park, Y.W., Juárez, M., Ramos, M., Haenlein, G.F.W. (2006): Physico-chemical characteristics of goat and sheep milk. Small Ruminant Research 68, 88-113. https://doi.org/10.1016/j.smallrumres.2006.09.013

20. Sutherland, M.A., Rogers, A.R., Verkerk, G.A. (2012): The effect of temperament and responsiveness toward humans on the behaviour, physiology and milk production of multi-parous dairy cows in a familiar and novel milking environment. Physiology and Behavior 107, 329-337. https://doi.org/10.1016/j.physbeh.2012.07.013

21. Szentléleki, A., Nagy, K., Széplaki, K., Kékesi, K., Tőzsér, J. (2015): Behavioural responses of primiparous and multiparous dairy cows to the milking process over an entire lactation. Annals of Animal Science 15, 185-195. https://doi.org/10.2478/aoas-2014-0064 